\title{
Recurrent Acinic Cell Breast Carcinoma
}

National Cancer Institute

\section{Source}

National Cancer Institute. Recurrent Acinic Cell Breast Carcinoma. NCI Thesaurus. Code C153568.

The reemergence of acinic cell breast carcinoma after a period of remission. 